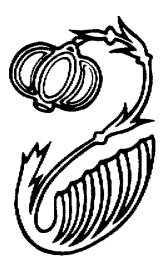

\title{
Miasma, Mimesis, and Scapegoating in Euripides' Hippolytus
}

Nisus ait: "dine hunc ardorem mentibus addunt,

Euryale, an sua cuique deus fit dira cupido?"

- Aeneid 9.184-85

$\mathrm{E}$ URIPIDES, As René Girard observes of Shakespeare, "in the portrayal of certain characters seems to oscillate between two opposite, really incompatible poles. On the one hand he makes these characters quite distinctive, especially as 'villains'; on the other hand he shows these same characters behaving and thinking exactly like their antagonists." 1 Thus in the Hippolytus, quite different characters come to act like their opponents in the course of the play's action. The young virgin Hippolytus comes to sound and act like the mature, sexually experienced Phaedra; Phaedra like Hippolytus; and Theseus like Hippolytus. Even Artemis resembles her opposite, Aphrodite, at the play's end. Furthermore, all characters seek eventually to revenge themselves reciprocally on one another, and in this reciprocity arises the play's disaster. I shall attempt to show how these two processes unfold in Euripides' Hippolytus.

Euripides' Hippolytus enacts a crisis of values, self, and community as its dramatic structure exposes the shaky foundations of the individuality that its

Work on this paper was interrupted by news of the death of George Walsh, who was my first Greek teacher and my friend. While George might not have agreed with aspects of this article, I dedicate it to his memory. Part of this article was presented at the January 1989 APA Annual Meeting in Baltimore to a generous audience. For their considerable help on the various versions of this study, I would like to thank Albert Cook, David Konstan, Georgia Nugent, Charles Segal, Daniel Tompkins, and the anonymous referees and Thomas Habinek of Classical Antiquity.

1. René Girard, "Hamlet's Dull Revenge," Stanford Literature Review 1 (1984) 159-200. 
characters repeatedly claim. An almost obsessive repetition of key words, phrases, actions, and scenes dissolves the alleged uniqueness and intentionality of the character who performs an individual act or speaks an individual word. Language ceases to represent a particular speaker's consciousness, but instead situates that character as a speaking subject in a larger text that speaks meanings through the character that the character cannot know. However, merely observing these patterns will not lead us anywhere unless we ask their cause.

In focusing on difference and its loss, on individuality and imitation, I employ the concepts of René Girard, ${ }^{2}$ who sees culture as a structure of differentiation masking a primordial mass of "indifferentiation." When this structure at times collapses, humans come into mutual conflicts generated from what Girard has called "mimetic desire": the phenomenon whereby one desires something not for itself, but because another desires it. In the rivalry for the object, one's imitation of the other's desire effaces one's identity. The differences among individuals collapse, antagonisms heighten, creating a mechanistic monstrosity feeding on itself until a scapegoat is found to permit redifferentiation by assigning blame arbitrarily to one person, thus halting the centripetal collapse. Self and community thus reestablish themselves through victimage. Finally, since the victim becomes seen as the solution to the mimetic crisis after having been viewed as its cause, the sacralizing violence of scapegoating incorporates the victim into the new divinely sanctioned structure.

However, moving from Girard's sometimes overly generalizing thought to an examination of a specific text presents a distinct problem concerning the arbitrariness of the play's chosen scapegoat. ${ }^{3}$ Girard's pursuit of a totalizing system leads him to insist, in the face of contrary textual evidence, on Oedipus's innocence. Similarly, any attempt to read Hippolytus as a pure scapegoat is undermined by his clearly impious behavior, and yet he functions, as we shall

2. René Girard, La violence et le sacré, (Paris, 1972); translated by Patrick Gregory as Violence and the Sacred (Baltimore, 1977). (All references will be to the English edition.) For further reading, see Girard's To Double Business Bound: Essays on Literature, Mimesis and Anthropology (Baltimore, 1978), and, most recently, "Generative Scapegoating," in Violent Origins: Ritual Killing and Cultural Formation, ed. Robert G. Hamerton-Kelly, (Stanford, 1987). This last book, a dialogue among Girard, Jonathan Smith, and Walter Burkert, is essential for anyone interested in these questions. On the transformation of the victim from criminal cause to divine solution, see Girard's Things Hidden since the Foundation of the World (Stanford, 1987). There has been an unusually violent argument over Girard's ideas. For a sample, see Hayden White, "Ethnological 'Lie' and Mythical 'Truth,'" Diacritics 8 (1978) 2-9; Philippe Lacoue-Labarthe, "Mimesis and Truth," ibid. 10-23. A useful analysis is Josue Harari's "Critical Factions/Critical Fictions," in Textual Strategies: Perspectives in Post-Structuralist Criticism, ed. J. Harari, (Ithaca, N.Y., 1979), 53-60. On Girard and Greek tragedy, see F. T. Griffiths, "Girard on the Greeks/The Greeks on Girard," Berkshire Review 14 (1979) 20-36; Carl Rubino's review article in MLN 87 (1973) 986-98; Helene Foley, Ritual Irony: Poetry and Sacrifice in Euripides (Ithaca, N.Y., 1985), esp. 46-64. Albert Henrichs has launched perhaps the most hostile attack on Girard in "Loss of Self, Suffering, Violence: The Modern View of Dionysus from Nietzsche to Girard," HSCP 88 (1984) 205-40.

3. Pietro Pucci gives the most recent criticism of Girard's theory of the arbitrariness of the scapegoat: “The Tragic Pharmakos of the Oedipus Rex," Helios 17 (1990) 41-50. 
observe, as a scapegoat because he is punished by the community for a different crime than Aphrodite's indictment and because he suffers for the misdeeds of others. Both innocent and guilty, both arbitrarily and legitimately punished, Hippolytus exposes originary violence. Scapegoating thus functions far more complexly in tragedy than in myth, and I shall argue that the Hippolytus further reveals the concealment of originary violence by representing the creation of a myth at the play's end that attributes all violence to the gods.

Since the Hippolytus does not represent overt acts of divine retribution such as Apollo sending a plague or Dionysus destroying the palace, it may not seem like a play depicting a sacrificial crisis, but in fact the characters of the Hippolytus pursue actions deeply determined by religious concerns like piety and pollution that directly cause a sacrificial crisis of distinctions. Phaedra fights against the legacy of her Minoan past,${ }^{4}$ while Theseus has been exiled from Athens because of his blood guilt, and his past is full of dark actions like his fatal negligence toward his father and darker figures like Medea. ${ }^{5}$ From Aphrodite's opening remarks about Theseus's exile, to the increasing effect Hippolytus's impiety has on others, to the cataclysmic violence at the seashore, to the institution of the cult to Hippolytus for all the maidens of Troezen, it becomes progressively clearer that this drama enacts not just one man's struggle against a god but that struggle's effects on the community. Hippolytus causes a sacrificial crisis by refusing to honor Aphrodite and by engaging in behavior that disrupts normal

4. On Crete's importance for Phaedra here, see Kenneth Reckford, "Phaedra and Pasiphae: The Pull Backward," TAPA 104 (1974) 307-28.

5. Ulrich von Wilamowitz-Moellendorff stresses the connections between the stories of Aegeus, Theseus, and Hippolytus to the point of suggesting a possible trilogy: "Excurse zu Euripides' Medea," Hermes 15 (1880) 482ff. Albin Lesky finds Wilamowitz's speculation "unsicher": Die tragische Dichtung der Hellenen, 3d ed. (Göttingen, 1972), 381. On Euripides' long fascination with these stories, see Bernard Knox, "The Medea of Euripides," YClS 25 (1977), esp. 193-95. Lesky provides a wealth of information on the relative dates of the plays and the pertinent myths. Further, Theseus's bloodstained lineage complicates his own acts of pollution. The play several times mysteriously hints at a polluted past for the family, which it never explicitly reveals. Theseus, after he has found Phaedra but before his discovery of the letter, indicates that Phaedra's death has come as the

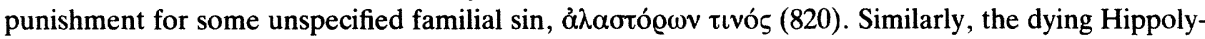

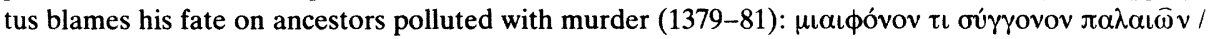

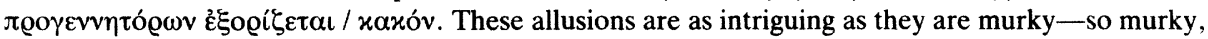
in fact, that most commentators pass over them. G. Devereux, for one, points out these passages, but offers no solutions or suggestions: The Character of the Euripidean Hippolytos: An EthnoPsychoanalytical Study (Chico, Calif., 1985) 95-96. W. S. Barrett in his commentary (Euripides: Hippolytus [Oxford, 1964]) has nothing particularly useful on these lines, and C. P. Segal ("Shame and Purity in Euripides' Hippolytus," Hermes 98 [1970] 296) notes that Hippolytus and Theseus "speak vaguely" of some inherited pollution. Wilamowitz (483) notes with suspicion that scholiasts have suggested the blood guilt from the Pallantids' murder as the reference here. Wilamowitz might be suggesting that Hippolytus in 1380 is referring to Aegeus and Medea, since the focus of Wilamowitz's argument is on the larger connections among, and the possible trilogy about, Aegeus, Theseus, and Hippolytus. It seems unlikely anyway that "old bloodmurders" can refer to deaths so recent as the Pallantids'. Nonetheless, both Wilamowitz and Hans Herter ("Theseus und Hippolytus," $R h M$ 89 [1940] 273-92) neglect Theseus's comment at 820 and the possible connection it might have with $1379-83$. 
societal patterns. Since Hippolytus's impiety toward Aphrodite will be discussed in detail later, we shall focus here on how Theseus's blood guilt deepens the sacrificial crisis incurred by his son.

Euripides subtly underlays the play's action early with a foundation of blood guilt linked with the subsequent action. In the prologue Aphrodite explains Theseus's exile from Athens, due to a pollution ( $\mu$ í $\alpha \sigma \mu \alpha)$ because he killed his cousins the Pallantids (34-37). ${ }^{6}$ Hence, a violation of the religious order causes Theseus's very presence in Troezen, but the disaster in his own home does not occur until he leaves for several days to consult an oracle. Euripides, however, delays revealing his whereabouts until his arrival (790ff.) and even then omits why Theseus has consulted the oracle. ${ }^{7}$ Surely Euripides had something in mind in keeping Theseus out of the play's first half. Or, put in other terms, the larger mythic text created a structure of events that would require Theseus's absence and give this absence a significance conforming to the mythic paradigms functional in the play.

We know generally that Theseus has long been involved with the gods, and we learn specifically from the play that he has $\mu i \alpha \sigma \mu \alpha$; his consulting the oracle about this pollution seems possible, if not likely ${ }^{8}$ Considering the importance of the correct observation of ritual and pollution in this play, we cannot ignore Theseus's whereabouts before his entrance. Perhaps, stained with his cousins' blood, Theseus approaches the oracle, but like Heracles at the altar in Euripides' Heracles, ${ }^{9}$ Theseus, because of his pollution, cannot come in contact with the oracle's divinity without something terrible happening; Theseus brings pure violence, sacrifice, and impure violence, murder, too closely together. Further, his $\mu i \alpha \sigma \mu \alpha$ proleptically structures his decision to use on his son Poseidon's curse, especially since Theseus has already killed other relatives whose name means "virgins"; one violent act prefigures the other. Hence, Theseus's blood guilt breeds more violence.

Given Theseus's past and the tainted history of Phaedra's family (which she herself evokes at 337-43) Hippolytus's refusal to honor Aphrodite finalizes a

6. This is Euripides' invention and should thus be carefully considered. See Barrett (supra, $\mathrm{n}$. 5) on 34-37, and Segal (supra, n. 5) 296. In a second legend, recounted by Pausanias (1.29.10), Theseus was tried for murder before the court of Delphinium and was acquitted for justifiable homicide. By employing a legal solution to this problem, this would seem to be a later version of the myth. All references in this paper are to Barrett's text.

7. Barrett (supra, n. 5) suggests ad loc. that Euripides invents the oracle merely because "he needs to get Theseus out of the way" and "he chooses an oracle for the sake of a convenient dramatic effect." This is too easy. It seems unlikely to me at least that in a play as densely woven and complex as the Hipp. Euripides would leave unexplained a fact as important as the cause of a major character's absence merely for the sake of expediency or dramatic effect.

8. Herter (supra, n. 5: 285) notes with slight skepticism that a scholiast has conjectured this: "und vor allem noch die Blutschuld auf sie trug, und so müsste man, wenn man genauer sein wollte als der Dichter selber, nach der Vermutung von Schol. 281 (vgl. 792) an eine Befragung des delphischen Orakels denken."

9. See Girard (supra, n. 2 [1977]) 39-41; Foley (supra, n. 2) 147-204. 
complicated series of crimes. Everyone in this family has some instance of pollution in the past, and all are endangered as a result. This danger is also communal for several reasons. First, Theseus's exile from Athens sets the paradigm for a community responding to an individual it perceives as dangerous. Second, a royal family's prominence entails that it bears a greater responsibility, and thus its crimes could affect the entire city. Third, the catastrophe that destroys Hippolytus at the seashore could be unleashed against the city-the type of divine violence Dionysus exacts on Pentheus's palace for behavior similar to Hippolytus's. The conflict between Hippolytus and Aphrodite is not just individual, but is further determined by his family's past and endangers everyone.

My approach here, emphasizing character as a member and function of community, also draws heavily from Harry Berger's studies of Shakespeare examining relationships among characters and how language expresses these relationships in certain psychological or ethical themes. ${ }^{10}$ Berger sees no significance in details like the number of children Lady Macbeth had, but in how their absence affects her interaction with Macbeth "as it reveals or betrays itself in the language they speak." One examines these themes and actions not in a single character but in the play's community, which Berger defines as a group of speakers structured by roles, ranks, and functions, and their concomitant assumptions and expectations. ${ }^{11}$ Berger observes that despite characters' initial avowed ethical positions, they "may shift position on the ethical spectrum; and the play may offer the audience a model of the ethical range that differs from any particular character's versions of it." 12 I shall try to show how in the Hippolytus mimetic desire drives these changes in ethical affiliation. Further, the characters do not see the ethical poles between which they move, nor realize the meaning of what they say; Hippolytus and Phaedra do not see the collapsing boundaries between their different, avowed values. A play's language as a whole continually indicates more than an individual means, and language determines a character's relation to another, to itself, and to the community, as well as to the audience.

These patterns of community, self, and change hold as true for the Hippolytus as for King Lear. I shall essentially continue the direction Bernard Knox indicated on the basic pattern of action the four principals share, ${ }^{13}$ while demonstrating in

10. See “King Lear: The Family Romance," The Centennial Review 23 (1979) 348-76; "Text against Performance: The Gloucester Family Romance," in Shakespeare's Rough Magic: Renaissance Essays in Honor of C. L. Barber, ed. P. Erickson and C. Kahn (Newark, N.J., 1985), 210-29; "Text against Performance: The Example of Macbeth," Genre 15 (1982) 49-70. Richard Levin, who views Berger as part of the "character assassination school" of criticism, criticizes this last article in "The New Refutation of Shakespeare," Modern Philology 83 (1985) 123-41. Berger answers Levin in the 1985 piece.

11. Cf. Berger (supra, n. 10 [1985]) 213. Berger's stress on the individual as a function of the whole shares a fair amount with John Jones's arguments against the overemphasis on the single protagonist on Greek tragedy in On Aristotle and Greek Tragedy (London, 1962).

12. Berger (supra, n. 10 [1979]) 349.

13. Bernard Knox, "The Hippolytus of Euripides," YClS 13 (1952) 3-31. 
addition the pervasiveness of patterns in general and the purpose of these patterns. The pattern of repeated, reciprocal violence in particular emerges, the most obvious instance being Theseus's condemnation of his son, but no character in the play owns a monopoly on anger. Hippolytus's hostile reaction to the Nurse, his aggressiveness toward his father, and Phaedra's incensed denunciation of the Nurse mirror Theseus's more extreme (in effect) but by no means unique violence. We will focus on the collapse of the distinctions between values, in the process questioning their intrinsic stability, the mimetic behavior of the play's characters, scapegoating, and then redifferentiation.

\section{STRUCTURE AND CHARACTER}

Before examining the relationships between the characters, let us first consider how the play's structure, its pervasive dualism, and the division of lines among the four principals contribute to destabilizing character and representing mimetic desire.

A symmetrical mirror image structures the whole play, pivoting on its structural center, the point when Phaedra departs the stage for her suicide. Surrounding her exit are, first, a pair of verbal confrontations, then the two scenes of pain and pity, and then the two goddesses' appearances. The mirror is not exact, as the final scene blends epiphany and Hippolytus's death, but it is close enough, and it is further strengthened by the striking mechanical repetition of Aphrodite's words and actions by Artemis, which in turn equates the two goddesses. ${ }^{14}$ Hence, symmetry and repetition mark the Hippolytus in terms of both character and structure. This loss of identity, what Girard calls "desymbolization," directly results from the sacrificial crisis.

The lack of a single dominating character contributes to the play's symmetrical and iterative nature. As Knox observes of the even division of lines among the four principals, "When the action of the play is so equally divided among four characters, the unity of the work cannot depend on any one, but must lie in the relationship of all four." 15 This quadripartite division allows for three extended, completely independent scenes of confrontation between characters, which when seen in the play's structure as a whole underline the similarity of these scenes. Their equal time emphasizes their equivalence. Faced with such a divided tragedy, our attention becomes drawn to what its characters share.

The Hippolytus tends to express all aspects of its world in a matrix of duality. Phaedra opposes her outside purity to her inside pollution and laments the two

14. See Knox (ibid.) 29-31. I do not suggest here that Artemis and Aphrodite are the same in the static world outside the play, but that placed in this setting of mimetic conflict, the gods fall prey to mimesis when they enter human affairs.

15. Knox (ibid.) 3. Devereux (supra, n. 5: 135) locates the "root of the calamity" in "the conjunction of - the interaction between-two potentially tragic characters," although this number should be three (or even four). 


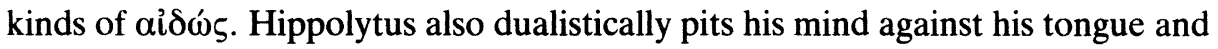
creates an additional double in the semantic and grammatical repetition of Phaedra's lament. Theseus wishes that men could have two voices to distinguish true from false statements. The two goddesses remarkably mirror each other. In addition to these doubling tendencies in speech and action, Euripides even more fundamentally stresses the double in the very essentials of the play's cast and scene structures. The dramatis personae consist of two female goddesses, two male mortals, two female mortals, a servant, and a messenger (this last pair fulfilling the same function in their respective scenes and presumably played by the same actor; hence, another double). ${ }^{16}$ Pentheus, at that critical moment of the Bacchae when Dionysus has destroyed his mind, sees two suns and two Thebeses, but in the Hippolytus instead of a moment of crisis this expands into the whole play so that characters see, think, and act doubly, even though they do not express this as directly as Pentheus.

These three textual qualities, then, help determine the interactions among the characters, and would normally tend toward order and stability; symmetry and repetition usually indicate or form structure and coherence. But in tragedy such repetitions signify disorder and instability, since they represent characters' imitations of one another; they show that what should be different has become the same.

\section{HIPPOLYTUS THE DESTROYER OF DIFFERENCE}

Turning to the problem of mimetic behavior in the play, we shall show first how Hippolytus becomes the destroyer of difference through his mimesis of the female and the perception that he has violated the incest prohibition. This will serve as an introduction to the larger question of mimetic rivalries. Then we shall turn to Theseus and Phaedra.

Hippolytus before the play's action has already assumed a large part of his identity as feminine in his claim to virginity and his identification with the mother over the father. ${ }^{17}$ Despite his spoken dismissal of females as individuals, he still sees part of their cultural status as desirable, although he probably does not view this part as feminine in itself, since he displaces it into Artemis, who is feminine-but also divine and virginal. Hippolytus possesses an underlying, repressed feminine part, a potential that Aphrodite seeks to bring to fruition.

16. Sir Arthur Pickard-Cambridge speculates on the possible distribution: "Perhaps (a) Hippolytus, Messenger; (b) Aphrodite, Theseus, Phaidra; (c) Servant, Nurse, Artemis. But the withdrawal of all three actors from the stage at more than one point (e.g. 120, 731, 1101) makes the distinction very uncertain" (The Dramatic Festivals of Athens, 2d ed. [Oxford, 1968], 145).

17. On Hippolytus and the feminine, see Charles Segal, "Pentheus and Hippolytus on the Couch and on the Grid: Psychoanalytic and Structural Readings of Greek Tragedy," CW 72 (1978) 129-48; Froma Zeitlin, "The Power of Aphrodite: Eros and the Boundaries of the Self in the Hippolytus," in Directions in Euripidean Criticism: A Collection of Essays (Durham, N.C., 1985) 52111; Devereux (supra, n. 5). 
His proclivity toward the feminine both begins and necessitates his mimesis of Phaedra. His virginity both underlies his behavior and incurs Aphrodite's wrath. While the women in the play have no such aspiration to virginity (being, of course, past that stage), in Greek culture virginity is a virtue appropriate to a young female, not a male. As Froma Zeitlin points out, by Hippolytus's mimesis of the feminine "the play is, in a sense, simply acting out what Hippolytus' claim to the status of parthenos $(1106,1302)$ implies, and therefore arranges his initiation into the world as resembling the experience of the female body." 18 His subsequent adoption of Phaedra's langauge and actions follows from his values; Hippolytus blurs the boundaries between the male and the female.

Paradoxically, however, in the course of undermining sexual difference, Hippolytus is accused of violating another type of sexual boundary: incest. This is a particularly striking substitution since incest and virginity function similarly by disrupting the normal structure of the family. These two sexual abnormalities depend on whether their effect is inside or outside the family, a difference constituted by the sexual code. A prohibition inside the family is not necessarily the same outside. To oppose sex with anyone (including outsiders) mirrors practicing it with everyone (including insiders), and thus has the identical effect of effacing the boundary altogether. Hippolytus, of course, does not actually commit incest, but Theseus perceives him as having done so, and perceptions are almost all that really matter here since an almost nightmarish sequence of misperceptions governs the play's action. Theseus's reaction to Phaedra's allegations and the family's structure suggest a prevalent concern in the play with incest. The basic tendency in Greek myth of fathers either absent or in conflict with their sons indicates a very ambivalent conception of paternity deeply encoded in Greek society and active in the Hippolytus.

Theseus's words several times indicate that he regards relations between Hippolytus and Phaedra as incestuous:

Hippolytus dared to touch my bed by force, having dishonored the holy eye of Zeus.

Look at him, who born from me shamed my bed and denies before her corpse being most base. Show your face here, since you've come into $\mu i \alpha \sigma \mu \alpha$, here to your father.

Then it was necessary to groan and realize when you dared to outrage your father's wife.

The combined language of parenthood, marriage, and sex indicates that Theseus regards Hippolytus's alleged rape of Phaedra not simply as rape, but as incest.

18. Zeitlin (supra, n. 17) 66. 
He stresses the father-son confrontation over the wife by the emphatic final

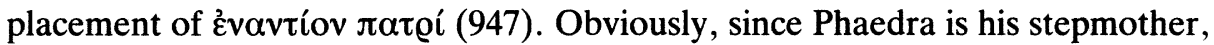
relations with her would not be just like Oedipus's with Jocasta, but Theseus's language clearly speaks of "father," "son," and "wife," and Hippolytus's language often returns to his mother (which we shall discuss in more detail later), so the structure of thought here suggests incest.

Most important, however, the key word $\mu$ í $\alpha \mu \alpha \alpha$ reappears. ${ }^{19}$ Theseus fled Athens to atone for the $\mu i \alpha \sigma \mu \alpha$ from his cousins' deaths (35). Phaedra worries about the $\mu$ í $\alpha \mu \alpha$ of her lust for Hippolytus (317). Now, similarly, Theseus sees Hippolytus as infected with $\mu i \alpha \sigma \mu \alpha$ from incest, and at the end Theseus fears that his son will leave him ơvarvov (1448). Incest and familial violence share the same designation, and hence a similar religious and cultural significance, as they both involve the dissolution of the terms of difference structuring the family and thus society. ${ }^{20}$ Hippolytus is accused of incest in the same language that might have been used if he had killed his real mother. Hence, violence and sex are superimposed together as the taboos against incest and killing relatives are broken. This leads us back to desymbolization and its causes.

Hippolytus's separation from the city, while trying to differentiate himself from others, adds to the threat his impiety toward Aphrodite seems to pose to it. His hunting companions merely follow him; for all practical purposes he has no family; and he does not participate in civic life. The Servant's pointed reminder to Hippolytus about the nature of piety shows how little he cares for the potential public consequences of his private actions. ${ }^{21}$ The Sophoclean hero's isolation also sets him in opposition to his community, but his or her isolation arises out of a dedication to a higher set of values, ${ }^{22}$ while Hippolytus's isolation, although cast religiously, masks his narcissism and elitism; Oedipus and Philoctetes can offer the world something, but Hippolytus's isolation is unto himself.

Living on the community's margins, Hippolytus continually risks violating its rules, and almost everyone raises some kind of accusation against Hippolytus: Aphrodite and the servant charge him with impiety; Phaedra privately with arrogance (í $\psi \eta \lambda$ ò $\varsigma$ عiv $\alpha \iota, 730)$ and publicly with attempted rape; Theseus with incest. The Servant, concerned with impiety's communal effect, worries that others will

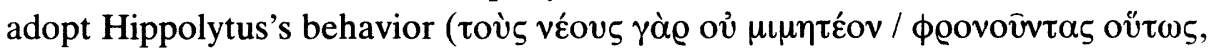
$114-15) .{ }^{23}$ The societal crime (incest) thus substitutes for the religious (impiety),

19. See Barrett (supra, n. 5: ad loc.), who compares the concept of pollution from sight in this play with the Heracles, where Heracles fears he will, after having killed his own children, pollute Theseus merely by speaking with or being seen by him.

20. A passage in Euripides' Andromache (173-76) also closely ties incest and intrafamilial murder.

21. On these points see Devereux (supra, n. 5) 59-64.

22. On Sophocles, see Cedric H. Whitman, Sophocles: A Study in Heroic Humanism (Cambridge, 1951).

23. Robert Parker observes, "Religious danger is almost always potentially communal in Greece": Miasma: Pollution and Purification in Early Greek Religion (Oxford, 1983) 10. Girard 
and only this charge allows the motivation for the violence that erupts against Hippolytus (like Oedipus). Hippolytus is perceived as a danger because he disrupts the distinctions between male and female, between piety and impiety, and finally the distinctions of kinship. Add to these instabilities his ambiguous status as bastard, hunter, foreigner, pseudo-Orphic, and adolescent, ${ }^{24}$ and Hippolytus becomes a veritable lightning rod for blame. Hippolytus is punished, then, because Theseus believes he has committed incest, but this punishment is essentially displaced from his disruptions of the community's sacrificial structure. However, we need to consider whether Theseus's charge has some truth after all, so we will now consider the problem of mimetic rivalry in the play.

\section{MIMETIC RIVALRIES}

\section{HIPPOLYTUS AND THESEUS}

Mimetic rivalries drive the conflicts in the Hippolytus. Girard's theory originates in an interpretation of Freud's theory of the Oedipus complex that denies that the child desires conflict with father, altering the rivalry from father-son to model-disciple by shifting the object of desire from the mother (object of sexual longing) to the father/model (object of imitation). ${ }^{25}$ The child adopts the father as model, adopts his desires, and "wants to take his place everywhere." Aristotle, it might be useful to recall here, argues in the Poetics $\left(1448^{\mathrm{b}}\right)$ that man learns by imitation, and Girard, synthesizing Freud and Aristotle, expands this into a theory of human behavior where disciples learn about the world by imitating models. When the father senses the child imitating his desire and choice of sexual object, the father responds negatively and violently, even though the desire is merely learned from a model. Here the "innocent" child learns of his Oedipal conflict: "The son is always the last to learn that what he desires is incest and parricide." 26 The Hippolytus essentially enacts this pattern of mimesis, rivalry, and then conflict by representing the young Hippolytus's discovery of Oedipal conflicts and mimetic rivalries.

While Zeitlin describes an "education of Hippolytus" in accepting eros through recognizing the Other since his rejection of eros is "the self's radical refusal of the Other," 27 I will argue that his education more involves realizing his own desires, since many of them are subconscious or underdeveloped. But this education involves more than Hippolytus and Phaedra, since so much of his selfperception depends on his relationship with his father, and so we will need to

(supra, n. 2 [1977: 114]) further argues that in times of crisis communal danger leads to the accusation of incest typically because the incest prohibition is so fundamental.

24. See Segal (supra, n. 17) esp. 134-35.

25. For a full explanation of the difference, see Girard (supra, n. 2 [1977]) 169-92.

26. Ibid. 174-75.

27. Zeitlin (supra, n. 17) 56. 
consider Theseus as well. ${ }^{28}$ Hippolytus has desired Phaedra because his past has especially psychologically conditioned him to an Oedipal fixation on "mother," 29 which he does not realize until it explodes to the surface at Phaedra's posthumous accusation. He is the last to learn about his desires. After having devoted himself to avoiding sexuality, Hippolytus finds himself confronted with his greatest fear: sexually aggressive parents.

Hippolytus's latent desire for the mother figure finally begins to take form in his language when the Nurse confronts him. Berger's terms accord well with this situation: ${ }^{30}$ "The language of the play says things about the speaker of which he is unaware." The extremity of his reaction, screaming (584), and the violence of his anger indicate that the Nurse has indeed touched upon a raw nerve. ${ }^{31}$ But his first words in this scene (immediately following Phaedra's statement of her plan to die) clearly reveal his real concerns (601-2): “O mother earth and the rays of the sun, such unspeakable words I have heard!" Faced with a sexual maternal figure he invokes, first, mother earth. Such an invocation in this situation cannot be merely rhetorically formulaic; Hippolytus may believe that he speaks in traditional votary terms, but his choice of "mother" betrays his emotional turbulence and fixation. The phrasing of his invocation's second half, "open sunlight," 32 is important because the reason for speech is a descendant of Helios himself, Phaedra, and because it combines with "mother." Thus, in both halves of this apostrophe, again as Berger says, ${ }^{33}$ Hippolytus "intends to communicate one message, but his language, speaking through him and in spite of his effort to control it, conveys another which he didn't intend." Hippolytus shows the power the possibility of desiring the mother exercises over him by the extent he represses the memory of this episode. Even considering his oath of silence, it is remarkable that he is so unflustered when he first speaks to Theseus and is so completely astonished and ignorant when Theseus has denounced him at length (934).

If at lines 601-2 Hippolytus's subconscious desires begin to trickle out, in his agōn with Theseus they rush out in a torrent. We shall consider first Hippolytus's three lines of self-defense (1009-15) to Theseus as to why the father should not think that his son would want to seduce his wife, and then what the very fact that

28. Critics have sorely neglected Theseus's role in this play, despite his considerable presence (he has as many lines as Phaedra) and his importance in the second half of the action and in determining his son's behavior. Herter's attitude is representative (supra, n. 5: 290): "In der ganzen Geschehen spielt Theseus . . . eine blosse Nebenrolle."

29. On Hippolytus's Oedipal fixations, see Devereux (supra, n. 5); A. V. Rankin, "Euripides' Hippolytus: A Psychopathological Hero," Arethusa 15 (1982) 181-201.

30. Berger (supra, n. 10 [1985]) 213.

31. Cf. Devereux (supra, n. 5) 64.

32. Barrett's translation. This is yet another word that returns to haunt Hippolytus; the messenger describes Hippolytus as, shortly before the bull appears, having stretched out his hands in

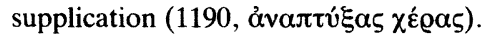

33. Berger (supra, n. 10 [1985]) 212. 
he offers these particular reasons indicates. He first raises Phaedra's beauty in a question, presumably to cast doubt on her appearance-not good tactics against a very recently bereaved husband. But more strangely, since he obsessively deemphasizes the visual, he chooses this as the first motive to disparage. In his defense a few lines earlier he remarks how he has seen, with great disgust, sexual activity represented graphically. So here again he seizes on the opportunity to deride the visual by questioning Phaedra's beauty. But if the visual means less to Hippolytus, then her beauty (or lack of it) should not be a concern to him and should not occur to him as the first issue, an inconsistency showing again how the prominence of his concerns in his language indicates the opposite of his conscious intention, and this tendency, I believe, outweighs an argument that the question of Phaedra's attractiveness would naturally first occur to anyone accused of attempted rape.

The next suggestion, that Hippolytus intended to become master of house and kingdom by marrying Phaedra, is peculiar in several ways. First, after seducing Phaedra he would still need to kill Theseus. We will return to this point shortly. Second, no one has suggested anything about marriage (

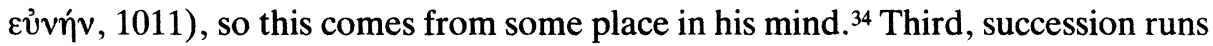
to Theseus and Phaedra's legitimate children first, not to the bastard Hippolytus. Part of Phaedra's obsession with her children's legacy (305-6, 420-25) could be maintaining this succession. And again, Hippolytus himself introduces this idea to the debate: unlike Creon's disavowal of political ambitions after Oedipus's paranoid accusations, Theseus has said nothing about plots against himself. If these things are "not at all in mind" (1012), then why does Hippolytus so often return to them? He next argues to his father, the king, that wise men avoid governing, which (typically) does not show much prudence. ${ }^{35} \mathrm{He}$ says he wants to remain "second in the city," but he can never be second in the city. Moreover, at the present he seems to play no civic role anyway, so this claim must be seen as part of Hippolytus's narcissistic self-aggrandizement. ${ }^{36}$

While Hippolytus's defense continually responds to unspoken accusations, ${ }^{37}$ Theseus's long speech (936-80) basically criticizes and ridicules Hippolytus's way of life, but, like Hippolytus, he offers three linnes of reasoning that

34. Granted, he could be suggesting possible motives that a defensive husband might adduce, but so many of Hippolytus's problems stem from marriage (or the lack thereof) that I do not think that he could have completely conscious control over this statement's meaning.

35. Barrett (supra, n. 5: ad loc.) "tact is not this young man's strong suit."

36. On Hippolytus's grandiosity, see Devereux (supra, n. 5) 115-19. Barrett (supra, n. 5) tries to read these lines as a literal statement about government in Athens and finds in their vagueness a Euripides who does not want anyone to "think beyond." I doubt that in such a nuanced, revealing, and important scene as this Euripides is not thinking clearly about what he writes and does not want anyone to think about it. I also doubt that the clever philologist here catches the careless poet. Comparable is the tendency to think that if a detail in a Shakespeare play does not at first make sense, then Will must have been in a hurry that day.

37. Contrast this with how the Nurse always carefully extracts information from Phaedra. 
attempt to answer arguments before they are made: first (958-61), that Phaedra's corpse proves the charge in itself; second (962-65), she never would have killed herself merely to make the charge more credible; third (966-70), men are just as sexually wanton as women. The last of these three underlies the first two, and here he shows himself, even in this emotional tirade, much more reasonable and progressive than his misogynistic son. Father and son's accusations and defenses do not counter each other point by point except on the matter of Hippolytus's sexuality. Hence, Theseus does not raise questions of marriage and political usurpation; he only expresses bitter cynicism toward his son's alleged sexual purity.

Hippolytus suggests marriage and politics as motivations for raping or seducing Phaedra, but the success of such an elaborate scheme would require that he kill Theseus as well as replace him in bed. Hippolytus's three lines of defense, then, suggest a latent desire to kill his father, ${ }^{38}$ which receives a more revealed expression later (1042-44): "If you were the son and I your father, I would kill you and not exile you if you thought to touch my wife." Switch roles, the son says, and he would kill the father. In this extraordinary statement, Hippolytus responds to his father's violent condemnation by expressing his repressed desire for reciprocal destruction. Seen in isolation, we could take this remark at face value, but given Hippolytus's pattern of unintended revelations and his resentment about his bastardy and his memories of his mother, the text seems likely to express here Hippolytus's desire to kill his father. Theseus condemns his son to death in his first rage (887-90), but then, in a slightly more rational moment, to exile (893-98). Hippolytus, managing his argument with as much reason and control as could be expected, pronounces a sentence of death for his father, but being ignorant of his father's initial outburst he cannot know the true symmetry of his parricidal wish.

This role-reversing, murderous wish underscores and brings to a climax the symmetry of this scene's reciprocal violence. By this point in the action we have seen enough of Hippolytus and Theseus to know their fundamental similarities and their increasingly mimetic behavior. Hippolytus, while trying to live a life unlike his father's, has actually led an existence that in many ways is a small-scale model of Theseus's. For one, his hunting is a lesser imitation of Theseus's killing of monsters. Both Theseus and Hippolytus are abnormal sons obsessed with their fathers; Hippolytus worries about his illegitimacy, and Theseus about Poseidon's paternity. In fact, Hippolytus the bastard is the mirror image of Theseus, the man with two fathers. Both react with extremely violent anger to suggestions of sexual impropriety. Both arrive on stage crowned with votary garlands, em-

38. On Hippolytus's murderousness, see Devereux (supra, n. 5) 72-75. Also, Jan Bremer observes that accusations of parricide often accompanied accusations of incest, a pattern that the events of this play could reflect: "Oedipus and the Greek Oedipus Complex," in Interpretations of Greek Mythology, ed. J. Bremer (Totowa, N.J., 1986), 41-59. 
phasizing the piety each is trying maintain. ${ }^{39}$ These are not minor details, nor are they few in number, and they lay the foundation for the symmetrical violence of the great, tragic confrontation between father and son.

Their behavior becomes increasingly mutually mimetic as the agōn progresses. Theseus's bitterly sarcastic criticism of Hippolytus (936-80) strongly resembles the blind fury of Hippolytus's denunciation of women (616-68). Hippolytus's immediate response to Theseus tries to reassert his difference from everyone else (980-1001), which is doomed because either he does not respond to Theseus's charges or his mode of argumentation digs him deeper into the hole and because it is his difference that has put him in trouble in the first place. The text's physical fabric, as we observed earlier about the play as a whole, underscores the scene's symmetry as the long speech of each is of roughly the same length and they engage in the give-and-take of the tragic stichomythia. ${ }^{40}$

In the course of the stichomythia, and after Hippolytus makes his murderous role-reversal plea, Theseus condemns Hippolytus (just as Phaedra had done) to repeat his experiences. Theseus progressively shifts the sentence from death to death or exile to, finally, just exile (1045ff.). Theseus earlier in the scene has described his son's $\mu$ í $\alpha \mu \alpha$ (946), a word Aphrodite used for Theseus's own exile; so it now tragically joins father and son: just as Theseus earlier in the debate projects his amorous own youth onto his son, he now sentences him to undergo the same punishment he has experienced for pollution.

Theseus completes the mimesis by assuming his son's impious language. As his so carefully constructed self unravels before him, Hippolytus takes an interest in religion other than devotion to Artemis and pleads with his father to test his oath or consult a prophet before his exile (1055-56). Conversely, Theseus, after his arrival on stage piously attired, now dismisses all such trappings in his maddened grief. His response to his son recalls (unconsciously imitates) Hippolytus's greatest insult toward Aphrodite in the first scene: "To your Cypris I say long

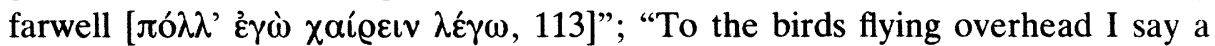

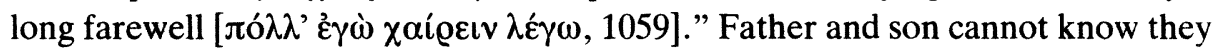
imitate one another in their confrontation. The larger symmetries of the text serve to emphasize and structure both the mimesis and the characters' ignorance of the mimesis, and speak larger meanings than the characters can ever hope to know or control. With this impious statement Theseus has placed himself in Hippolytus's position. Artemis will inform Theseus of this (1320-24) and call his behavior ó $\mu \alpha \varrho \tau i \alpha$ (1334) just as Aphrodite characterized the nature of Hippolytus's impiety to the audience also (ínó $\varrho \tau \eta x \varepsilon, 21)$. One might say here (with apologies to Wordsworth) that the child is father of the man.

39. Also, both Theseus and Hippolytus would, crowned with garlands, initially address static female figures: Hippolytus the statue of Artemis, Theseus the corpse of Phaedra.

40. The piling-up of arguments, relevant or not, is characteristic of the agön in tragedy and probably reflects courtroom practice; cf. Richard Garner, Law and Society in Classical Athens (New York, 1987). 


\section{HIPPOLYTUS AND PHAEDRA}

Since Dodds ${ }^{41}$ critics have studied often and insightfully the similarities between Hippolytus and Phaedra, but often while neglecting similar features in the rest of the play, or without probing into why the initial differences between Hippolytus and Phaedra collapse as the action progresses..$^{42} \mathrm{We}$ will first study briefly Hippolytus's mimesis of Phaedra, Phaedra's of Hippolytus, finally reintroducing Theseus by studying the values each expresses and how they express them. All three struggle over the meaning and value of such key words as aíós,

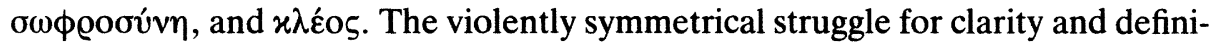
tion so involves the characters in defining their values against the others that the values themselves recede into the background and are replaced by the desire for and the conflict over definitions. The desire, that is to say, ceases to be physical, but becomes metaphysical. The Nurse, with her misguided but instinctual practicality, senses this shift from the physical to the metaphysical and exclaims (49091): "Why speak so high and mighty? You don't need fine words, but the man." Despite her opportunistic rhetoric, the Nurse seems to have hit upon something here: Hippolytus and Phaedra, and later Theseus, have substituted for an objectbased desire a text-based desire - a desire for the desire of the other, or, a desire that consists of the discourse of the other. The mimesis finds expression when they imitate the values and words each of the other, leading to a struggle over the meaning of words and the words themselves.

Man, Lacan reminds us, ${ }^{43}$ is born into language, and language forms man: "Man speaks, but it is because the symbol has made man." This becomes especially apparent in a tragedy like the Hippolytus, where individual words hold an almost demonic control over the characters and where the self comes into question. Thus, the self appears to be a construct of values (texts) and desires that is arbitrary and easily destabilized. In the Hippolytus the sacrificial crisis destroys language's ability to function as a means of expressing individuality and intentionality, or (for Lacan) of seeming to expose these, as the characters continually exchange values and characteristics. Either a signifier like $\alpha i \delta \omega \varsigma$ or $\sigma \omega \phi \varrho o \sigma u ́ v \eta$ guides a character in blind obedience to its power, or the signifier forms part of a discourse that one character imitates in another, or the signifier is part of a larger discourse in which a character unknowingly participates. The signifier gains control over the self and

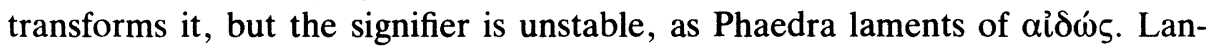
guage, as Lacan says, does not belong to the self, but it reflects otherness. $102-10$

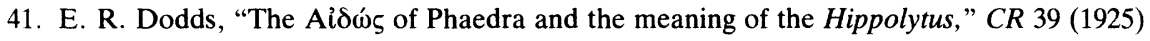

42. Zeitlin's recent study (supra, n. 17) has corrected many, but not all, of these problems, neglecting the other imitations in the play and the more general problem of desymbolization. This absence probably stems from her neglect of the incest problem. See David Konstan's review in Comparative Drama 20 (1986) 82-85.

43. Jacques Lacan, Ecrits: A Selection (New York, 1977) 65. (Ultimately, as Prof. Cook reminds me, the point is Cassirer's.) However, for Lacan there is no undivided self, no real self. 
Let us take a substantial, but by no means complete, set of key words from the Hippolytus and examine their speakers, their context, and their frequency.

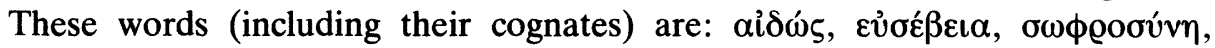
$\varepsilon v ื x \lambda \varepsilon\llcorner\alpha$. This will show how the characters employ a communal language but no longer agree over the meaning or usage of words, and how the characters' selves consist of a set of texts, of discourses, that are interchangeable. These words say

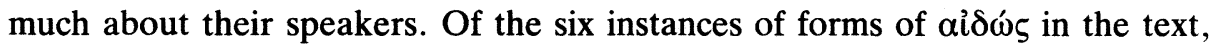
Hippolytus discusses himself in two $(78,998)$; Phaedra worries about her immediate behavior in two $(244,335)$ and in another about the two types of $\alpha i \delta \omega_{5}(385)$; and in the sixth Theseus respects religious custom (1258). Hence, through the prism of this one term we see their basic characteristics. All three face disruptions in their lives by attempting to reassert their definitions of human society and behavior. Hippolytus uses these four words fifteen times almost exclusively to praise himself, ${ }^{44}$ only including others to compare himself favorably (667, 1034-35). In contrast, Phaedra uses these words to reflect on her situation and humanity in general eleven times. ${ }^{45}$ Theseus employs them about Hippolytus three times and another two about his own affairs. ${ }^{46}$ Here we see the true mark of the narcissist in Hippolytus. Societally, we see someone appropriating the discourse of religion and virtue as his own.

Evंoź $\beta \varepsilon \iota \alpha$. Hippolytus especially lays claim to piety. Nine of the twelve instances of $\varepsilon \dot{\sigma} \sigma \varepsilon \varepsilon \varepsilon \iota \alpha$ involve Hippolytus. ${ }^{47}$ The three exceptions, however, are extremely important. In the first, Phaedra gives in to the external sense of shame by honoring the Nurse's suppliance (244). In another Theseus speaks of Poseidon honoring his promised curses (896). Most important, Aphrodite first uses this word and thus shades all its future instances (5-6). ${ }^{48}$ Piety for Aphrodite means honoring her; for Hippolytus it means honoring Artemis. Mortal pits definition against immortal. Mortal loses. Aphrodite's view of Hippolytus's chastity as impiety makes his piety extraordinarily ambivalent and unstable. Perhaps a subconscious recognition of this causes his incessant proclamations of his virtue and piety. Hence his very use of the word at a key moment actually contributes

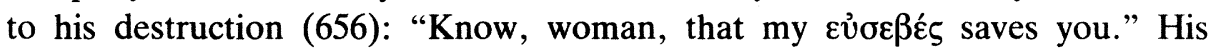
$\varepsilon \cup ̉ \sigma \varepsilon \varepsilon \varepsilon \iota \alpha$ here resembles Phaedra's $\alpha i \delta \omega ́ s$ where she gives in to the Nurse in similar language (335): "I feel shame before the oé $\beta \alpha \zeta$ of your hand." The recent

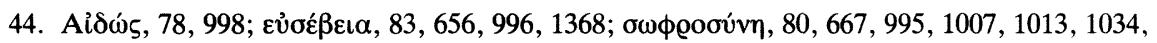
1100,1365 ; $\varepsilon v ้ x \lambda \varepsilon \iota \alpha, 1028$. In 78, 80, 667, 998, and 1013 Hippolytus is indirectly referring to himself or establishing a group in which he implies his membership. In 1034 he compares Phaedra's unnatural $\sigma \omega \phi \varrho o \sigma u ́ v \eta$ to his failure to exercise his own. In 1028 he is obviously not praising himself.

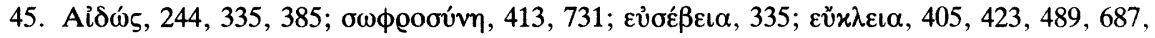
717.

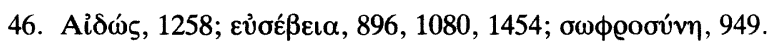

47. $83,656,996,1061,1080,1339,1368,1419,1454$.

48. On Aphrodite's establishment of the play's language and imagery, see Charles Segal, "The Tragedy of Hippolytus: The Waters of the Ocean and the Untouched Meadow," HSCP 70 (1965) 120-21. 
memory of Phaedra's similar remark disrupts our reading of line 656. Like

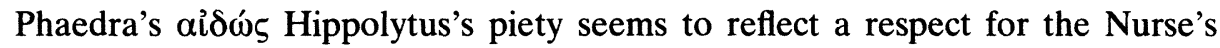
suppliance - that is, for externally motivated standards of behavior. Hippolytus's piety here saves neither the Nurse nor himself, but destroys him just as Phaedra's respect for convention ruins her. Just when he most needs his own sense of piety, it changes into something more appropriate to Phaedra. Forms of $\varepsilon v ่ \sigma \varepsilon ́ \beta \varepsilon \iota \alpha$, then, thrust Hippolytus into prominence and destroy him. He must learn that his form of piety is not the only one. Others, like his father, can be pious and hold special relationships with the gods also.

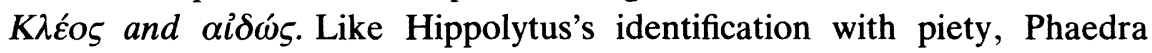
nearly monopolizes $x \lambda \hat{\varepsilon}$ oร, as six of its eight instances involve her. ${ }^{49} \mathrm{We}$ will hence study her usage of this value, what this indicates about her and the whole

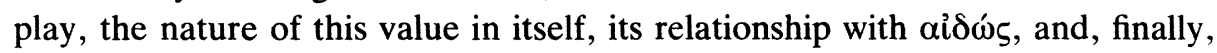
the significance of Hippolytus's growing concern with reputation in the play's second half.

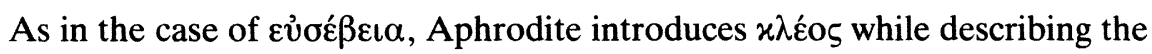
basic tension between Phaedra's reputation and her fate (47). Here reputation seems to be an admirable quality, as Phaedra has tried to lead a good life and has acquired a good name for it. This will change, since, as the action progresses, Phaedra's desire for reputation becomes less connected with reality than with preserving appearances (preserving the discourse of reputation). She attempts to conceal this growing split under the admirable wish for her children's welfare (421-23) that they might live free in Athens and be " $\varepsilon \dot{x} x \lambda \varepsilon \varepsilon i \varsigma$ because of their mother." This last phrase gives the ballgame away: her reputation is really at stake, not theirs. Phaedra's definition of $\varepsilon u ̈ x \lambda \varepsilon\llcorner\alpha$ slips further shortly later (48889): "One must speak not what pleases the ear but from what one will be

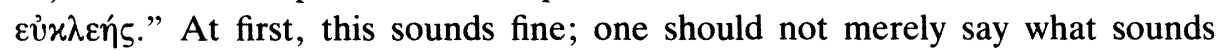
good, but what will give one a truly good name; but the real opposition here should be between pleasing speech and truth or virtue. Reputation may be desirable, but it is predicated upon virtue and is not virtue in itself. Reputation is not so exclusive of what sounds good as to prevent one from becoming the other, and Phaedra does blur the two together. ${ }^{50}$

Her culture has taught Phaedra that she must preserve a good reputation, and this has taken so firm a hold on her mind that she clings to it like a life preserver. It pleases her ear so much that she becomes willing to do anything in its name. And thus her angry rebuke to the Nurse after the latter has confronted Hippolytus expresses her consuming fear of losing her reputation: "We will no

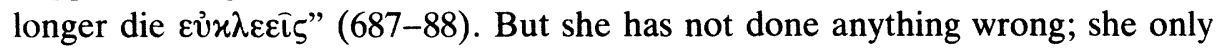
worries about the perception of sin. Finally, when announcing her plan of action, her sole concern is reputation (716-17): "I have a discovery for this disaster to 
prepare a $\varepsilon \dot{x} x \lambda \varepsilon \hat{\alpha}$ life for my children." It pleases her ear that she acts to preserve her own and her children's reputation, but this masks her lurking desire to revenge herself on Hippolytus (724-31). She thinks the deed will give her $\varepsilon v ้ x \lambda \varepsilon\llcorner\alpha$, but its infamy ultimately is immortalized in the songs of Hippolytus's cult. Phaedra's $\varepsilon$ u้x $\lambda \varepsilon\llcorner\alpha$ is as ambivalent and dangerous as Hippolytus's $\varepsilon \dot{v} \sigma \varepsilon \hat{\varepsilon} \beta \iota \alpha$, and the text establishes symmetry of effect here.

And while $x \lambda \varepsilon$ ćs is one of the fundamental values of the heroic code in Greek culture, it becomes very problematic, if not dangerous, in a tragic setting. In a comic plot, the hero of the Odyssey learns about the ambiguities and pitfalls of striving for $x \lambda \varepsilon$ Éo $\varsigma$ and can incorporate this new knowledge into his life,,$^{51}$ but Hippolytus and Phaedra (and Achilles, for that matter), in a far different context and poem, have little opportunity to adjust their values. $\mathrm{K} \lambda \dot{\mathrm{o}} \mathrm{\sigma} \varsigma$ is a disruptive, unstable value because it is mimetic. ${ }^{52}$ When desiring fame, one wants the desire of the other and the real subject of that desire, the self, and desire's immediate object begin to disappear under the haze of reputation and human communication's ambiguities. A warrior desires to kill Hector and strip his armor not for the killing and stripping itself, but because another desires to strip and kill and because the warrior will be desired in return if he kills and strips Hector. K $\lambda \varepsilon$ c $\varsigma$ is metaphysical, not physical, because it is based on the competitive imitation of other warriors.

Phaedra's psychology and concern with her reputation strongly resemble, yet pervert, the Homeric warrior's. ${ }^{53}$ While recognizing the possibility of other motivations and the problems generated by conflicting forces (383-87), ultimately her reputation-preserving suicide attempts to resemble the Homeric death-with-fame ethic. However, she transforms it: the warrior dies in a glorious deed that others will talk about forever, while Phaedra kills herself and leaves a text to insure another will be blamed and she will be praised. Or, in other words, the warrior risks his life for potential fame, while Phaedra kills herself in order to avoid ruining her reputation. Hence, half of Phaedra's two-sided morality depends upon a text that culture has encoded in her. Phaedra's concern with her reputation is equivalent to the outwardly oriented $\alpha i \delta \omega \varsigma$ of lines $383-87.54 \mathrm{Her}$ morality's other half, the inner sense of modesty and shame, she seems to acquire from Hippolytus's discourse.

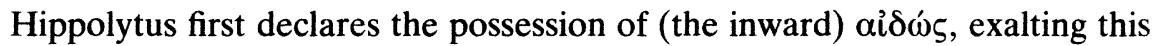
virtue above all (76-78), and Phaedra expresses her mimesis of Hippolytus in the

51. On $x \lambda \varepsilon \sigma_{\varsigma}$ and its problems, see Gregory Nagy, The Best of the Achaeans: Concepts of the Hero in Archaic Greek Poetry (Baltimore, 1979), esp. 28-29, 35-41.

52. See Girard's discussion (supra, n. 2 [1977: 151-53]) of $x \bar{v} \delta \circ$ s in Homer.

53. Segal (supra, n. 5) 284, 291; David Claus, "Phaedra and the Socratic Paradox," YClS 22 (1972) 230-35. On external versus internal motivation, see the first two chapters of E. R. Dodds, The Greeks and the Irrational (Berkeley and Los Angeles, 1951), esp. p. 18 for a specific account of aißós.

54. Segal (supra, n. 5) 283-84. 
following scene by passionately longing to hunt in the wild. I propose that her

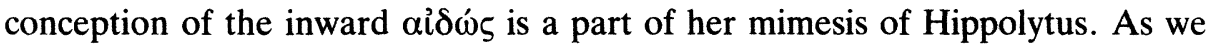
have seen, she has acquired the expressed desire for moderation and virtue through her desire for Hippolytus; she does not have them by nature. ${ }^{55}$ At the very least, her expression of it is a part of her mimesis of him. Phaedra's uses of

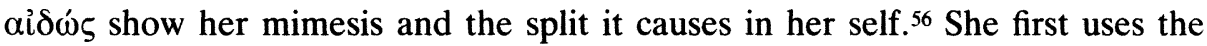
word (244), while she still controls her passion to some extent, in its internal

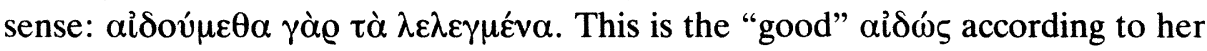
definition at 383-87), since here she concedes a personal sense of shame. But in her second mention of the word she has slipped to a "bad" or external one (paralleling the deterioration of her conception of $\varepsilon \cup$ x $\lambda \varepsilon\llcorner\alpha ; 335)$ : "I reverence

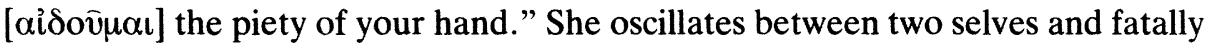

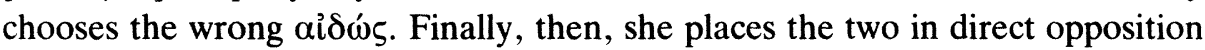
when lamenting the two types of $\alpha i \delta \omega \varsigma$ and the tension between knowledge and action (380-87). Phaedra gives herself over to the bad shame in a desperate attempt to preserve what she sees as left of herself. She tries to overcome the mimesis, but too late.

Hippolytus reciprocates the mimesis with a growing concern with reputation in the play's second half. Now while Hippolytus, according to his own claims, should preserve a consistency between appearance and truth, between inside and outside, he breaks this continuity with the famous remark (612) "My tongue is sworn, but my mind is unsworn," which remarkably resembles Phaedra's contrast between the purity of her hands and her mind's pollution (317). Hippolytus's self begins to divide when confronted with his stepmother's passion, and hence Hippolytus begins to speak in a structure of thought similar to Phaedra's. Hippolytus seems preoccupied with reputation. Someone who so constantly finds it necessary to praise himself must be obsessed with the preservation of his good name. After the official pronouncement of banishment, he casts

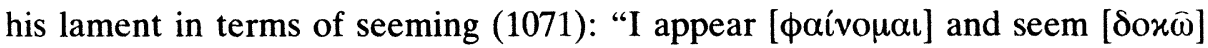
bad to you." The redundancy of the two verbs of appearance emphasizes this almost nightmarish split between reality and reputation, especially since Hippolytus is perhaps truly $\sigma \omega \dot{\phi} \varrho \omega v$ in refusing to reveal the truth to Theseus. Even while exiting the stage on the path to destruction he speaks mainly of how others see him (1100-1101): "You will never see a more virtuous man." One might argue that Phaedra's concern is with preserving a false $\varepsilon u ̈ x \lambda \varepsilon\llcorner\alpha$ whereas Hippolytus tries to keep his true $\varepsilon v ̋ x \lambda \varepsilon\llcorner\alpha$, but in the terms he uses his reputation is not necessarily true, since the play shows his virtues are not absolutely certain.

And so as Hippolytus plummets toward destruction his mind and speech

55. See Helen North, Sophrosyne: Self-Knowledge and Restraint in Greek Literature (Ithaca, N.Y., 1966) 80.

56. See Segal (supra, n. 5: 284ff.) for a general discussion of $\alpha i \delta \omega \varsigma$ and a bibliography on this much-discussed passage. 
increasingly resemble Phaedra's by connecting his reputation with his being. After swearing to Theseus that he did not touch Phaedra, Hippolytus laments his

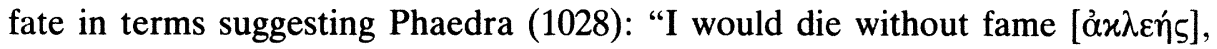
nameless." For the first time in the play, a form of $x \lambda$ ćo $\zeta$ refers to someone other

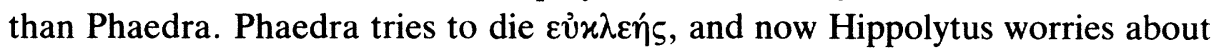
dying $\alpha x \lambda \varepsilon \eta \dot{\zeta}$. Hippolytus reminds one of Cassio after his dismissal by Othello (2.3.262-65): "Reputation, reputation, reputation! O, I have lost my reputation! I have lost the immortal part of myself, and what remains is bestial. My reputation, Iago, my reputation." In Othello reputation is seen to immortalize, and its loss to animalize, man. But, as in the Hippolytus, the excessive pursuit or loss of reputation can also easily destroy man. ${ }^{57}$

Artemis completes the change by vindicating Hippolytus to Theseus so the

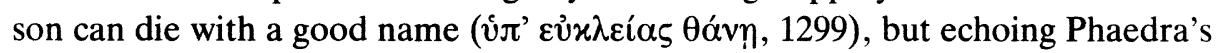

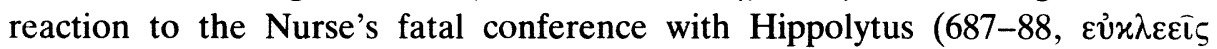
$\theta \alpha v o$ $\left.\mu \varepsilon \theta^{\prime}\right)$. Artemis thus recasts Phaedra's own desires into Hippolytus's legacy. Artemis's recognition of Hippolytus's $\varepsilon v ้ x \lambda \varepsilon \iota \alpha$ here is also symmetrical with Aphrodite's of Phaedra's (47). Artemis also restores Phaedra's reputation (1300-1305). With the crisis of the tragic moment past, $\varepsilon v ้ x \lambda \varepsilon\llcorner\alpha$ can become a safe value again.

$\Sigma \omega \phi \varrho o \sigma v ́ v \eta$. $\Sigma \omega \phi \varrho o \sigma u ́ v \eta$ serves as virtual battleground for the characters of the Hippolytus ${ }^{58}$ Both Phaedra and Hippolytus, and to a less explicit extent Theseus and the Nurse, speak at great length about $\sigma \omega \phi \varrho o \sigma u ́ v \eta$ as something about which each has a clear, though different, idea and for which each strives. However, each perceives and denies the other's difference concerning $\sigma \omega \phi \varrho o \sigma u ́ v \eta$ and strikes out violently against the immoderate rival. The word occurs in various forms sixteen times in the text; eleven for Hippolytus, six for Phaedra (with two overlapping for both), and one for the Nurse.

Hippolytus introduces $\sigma \omega \phi \varrho o \sigma u ́ v \eta$ in his general declaration of principles

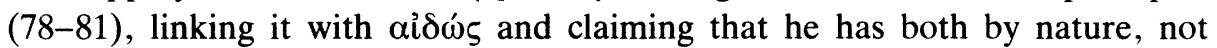
nurture, and displaying his characteristic extremism and irreality. ${ }^{59}$ For him, $\sigma \omega \phi \varrho o \sigma u ́ v \eta$ has sexual overtones, since he uses it to describe his chastity, and it often does so in Greek, but in regard to women. This anomaly underscores his orientation toward the feminine and undermines his rantings against the lack of $\sigma \omega \phi \varrho o \sigma u ́ v \eta$ in women. When pressed, Hippolytus falls back on $\sigma \omega \phi \varrho o \sigma u ́ v \eta ~ l i k e$ a crutch; his responses become almost knee-jerk. Concluding his tirade to the Nurse on the evils of women, he expresses the necessity either to stomp on them

57. There are many concerns shared between these two plays; for example, the fundamental similarity in the situations of Cassio and Hippolytus. But this would require a long analysis to do it justice.

58. For $\sigma \omega \phi \varrho 0 \sigma u ́ v \eta$ in Euripides, see North (supra, n. 55) 68-84.

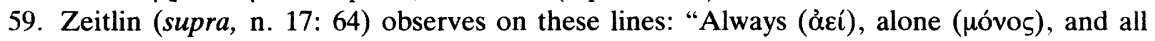
$(\pi \alpha ́ v \tau \alpha)(80,84)$, define the self in regard to this Edenic enclosure whose perfect circles of time and space exclude the temporal and the linear narrative of a human life." 
or to teach them self-control ( $\sigma \omega \phi$ goveiv, 667-68). In the process, he doubly contradicts himself, because, first, he himself displays a noticeable lack of moderation and control here; and second, according to his own words (79-81) $\sigma \omega \phi \varrho o \sigma u ́ v \eta$ cannot be taught. Moreover, his self-defense before his father immoderately, even overbearingly, insists on his moderation no less than three times in eighteen lines $(995,1007,1013)$, and a fourth twenty-one lines later (1034). And his last words leaving the scene add to the overkill: "You will never

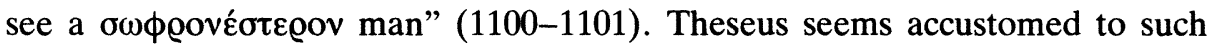
behavior from his son, sarcastically asking (949): "You are $\sigma \omega ́ \phi \varrho \omega v$ and unmixed in evils?" As Dodds has pointed out, "The last link in the chain of disaster is not Hippolytus' self-control, but his lack of it."60

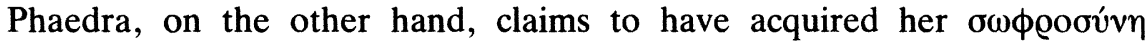
through practice in the struggles of life. She has fought to control her passion by

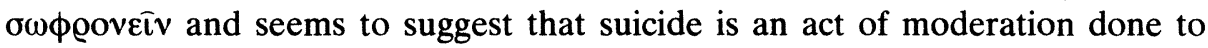
avoid acts of greater immoderation. (Hippolytus indicates as much at 1034-35.) But, nonetheless, suicide ultimately can hardly be considered moderation, and so, as with Hippolytus, her quest for moderation leads her into immoderation. Phaedra, then, also stresses the importance of moderation.

As the drama's conflicts take shape, moderation gives way to immoderate acts done in moderation's name, and the competition to possess $\sigma \omega \phi \varrho o \sigma u ́ v \eta$ creates a violent symmetry. Hippolytus, in his uncontrolled tirade against women, wishes to teach women control (667-68). Phaedra, in her final speech surrendering to Aphrodite, goddess of immoderation, almost identically vows to teach Hippolytus

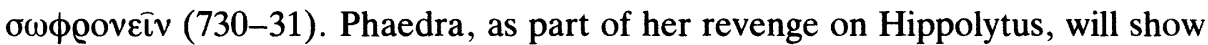
him his immoderation by making him "share in disease" with her, the disease of

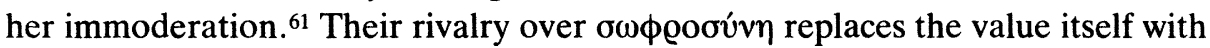
the desire for it, and further undermines the difference between the characters. Theseus exacerbates the situation with his sarcastic question to his son (949) and through his decidedly immoderate condemnation of him. ${ }^{62}$ So Dodds's observa-

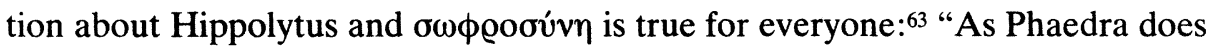
violence to aidōs, so does Hippolytus to sōphrosunē in the name of sōphrosunē." Desire levels and desymbolizes.

60. Dodds (supra, n. 41) 103.

61. Barrett (supra, n. 5: ad loc.) observes: "Eur. may have perhaps intended a special point in Ph.'s words. But I doubt whether an audience would have taken the point: nearly all talk of Hipp.'s $\sigma \omega \phi \varrho o \sigma u ́ v \eta$ comes later in the play." But I doubt any audience could ignore the statement that a major character must learn a quality that he has claimed as his special province earlier in the play. While most of the talk of his $\sigma \omega \phi \varrho o \sigma u ́ v \eta$ comes later in the play, Hippolytus's two earlier uses of the word at 80 and 667 are highly foregrounded, and overall there are eight instances of it in each half of the play. Further, the poet probably wants this instance to echo in his audience's minds later. So there is a constant concern with $\sigma \omega \phi \varrho o \sigma u v \eta \eta$ throughout. Moreover, an audience would surely weigh appropriately the last climactic words of a major character before a choral ode.

62. See North (supra, n. 55) 81.

63. See Dodds (supra, n. 41) 104. 


\section{SCAPEGOATING AND MYTHMAKING}

The collapse of difference in the Hippolytus spreads from character to character, threatening to engulf the entire community, a danger that all the characters sense, as the vehemence of their reactions shows, even if they do not consciously realize its nature or extent. Before these inversions can end, however, they must become pervasive: "For order to be reborn, disorder must first triumph; for myths to achieve their complete integration, they must first suffer complete disintegration." 64 This complete disintegration occurs when the monstrous bull arrives. The violence that erupts against Hippolytus, I will argue, is a form of symbolic collective violence that brings the community out of danger by transferring the violence that has been growing in the city outside the realms of the city and human responsibility into the hands of the gods. The myth of Hippolytus's death thus displaces human violence onto the gods. Hippolytus must become a scapegoat. ${ }^{65}$

Hippolytus typifies two types of scapegoat by being both marginal (as a bastard, hunter, virgin, and adolescent and sexually ambivalent) and royal, as the king's son. As central and marginal he easily attracts blame. By inhabiting Troezen while separating himself from the community, Hippolytus can serve as an effective surrogate victim, because he both resembles and differs from the community's members. Further, his continually excessive reactions prepare his victimization by disassociating the community and the audience's sympathy from him. As Kenneth Burke has said of tragic victimage in Shakespeare's Coriolanus, ${ }^{66}$ "The character to be sacrificed must be fit for his role as victim; and everything must so fit together that the audience will find the sacrifice acceptable (thereby furtively participating in the judgement against the victim, and thus even willing the victimage)." Everyone accuses Hippolytus of some transgression, whether impiety, arrogance, or incest. His precarious prominence in both piety and impiety endangers the community, since in a destabilized, mimesisprone community such as the play represents, Hippolytus could lead others down the same impious path, as the Servant worries in the first scene (115-16). ${ }^{67}$ But the charge of incest, not impiety, triggers the outbreak of violence against him. It does not matter that Hippolytus is innocent of incest; he is a suitable

64. Girard (supra, n. 2 [1977]) 79.

65. On the scapegoat in ancient Greece, see Jan Bremmer, "Scapegoat Rituals in Ancient Greece," HSCP 87 (1983) 301-20; Walter Burkert, Structure and History in Greek Mythology and Ritual (Berkeley and Los Angeles, 1979) ch. 3; Parker (supra, n. 23) ch. 9; J.-P. Vernant, in J.-P. Vernant and P. Vidal-Naquet, Myth and Tragedy in Ancient Greece (Brighton, Mass., 1981) 87-119.

66. "Coriolanus and the Delights of Faction," in Language as Symbolic Action (Berkeley and Los Angeles, 1966) 81. Coriolanus and Hippolytus resemble one another in that the excessiveness of each determines his downfall. Adrian Poole observes another similarity: "Like Coriolanus, he [Hippolytus] insists on saying things in public that are better kept under cover" (Tragedy: Shakespeare and the Greek Example [Oxford, 1987] 155).

67. On the destruction of cities by gods angry at an individual, see Parker (supra, n. 23) 272-73. 
bearer of this accusation since his impiety has placed him in a blamable situation. The establishment of a scapegoat always carries with it, in Girard's view, a degree of arbitrariness. In the myth's specific form as the tragedy represents it, the scapegoating seems less arbitrary by exploiting the ambivalence of Hippolytus's degree of innocence or guilt in order to engage the audience's emotions.

The conflicts peak when the human violence moves from the city to the wild seashore, and nature becomes a part of this obliteration of distinctions. ${ }^{68}$ The bull appears in a supernatural wave (iع@òv $x v \mu$ ', 1206-7) reaching the heavens, overwhelming with water the land (1205-9), a collapse of distinctions between sea, sky, and land mirroring the desymbolizations inside the city. The wrath of queen against her servant, son against father, queen against son, father against son, and son against everyone becomes reflected in (perhaps more accurately it creates) the violent obliteration of the natural world's structure.

The supernatural tidal wave and bull, along with the destructive panic they instill in the horses, represent the violent unaniminity of scapegoating by symbolizing human violence. The bull's capacity to represent certain aspects of every character's irrationality (see below) enables it to symbolize their collective irrationality, a process that begins the displacement of human violence onto the gods. I do not suggest that everyone in Troezen attacks Hippolytus with their bare hands and rips him to pieces, but that the combined forces of gods, family, and nature in the actual destruction of Hippolytus are a symbolic form of collective violence, which perhaps was represented more literally in earlier versions of the myth. As in Pentheus's death, the forces of man and nature combine to rend the youth to pieces. The horses now mangle and tear apart Hippolytus's body, engaging in a sparagmos (1234-39), all merging in one bloody mass. This could be a case of how, as Girard observes, ${ }^{69}$ collective murders are sometimes transposed in mythology onto groups of animals; the myth's historical development could have removed direct human participation as part of the removal of violence from man's responsibility.

When the bull enters after the collapse of the boundaries of the self between the inside and the outside, the crisis of distinctions dissolves the final borderline between the real and the unreal. The bull possesses an element of almost every character's destructive emotions: it is "an objectification of Theseus' anger,"70 a symbol of Aphrodite's wrath, of Phaedra's passion, and finally, and perhaps most important, the bull represents the wild, untamed sexuality that Hippolytus has always fought but that has always been inside him. He tries to see the apparition as something fundamentally outside himself, but it comes from his inside. After the border between the inside and the outside has fallen, the bull appears, in Girard's terms, as his monstrous double, a twofold projection of

68. See Segal (supra, n. 48) 143ff.

69. Girard (supra, n. 2 [1987]) 186.

70. Segal (supra, n. 48) 146. 
himself and Theseus, ${ }^{71}$ but since Hippolytus sees the bull as alien to his self, as something from the outside, he "conceals from himself the human origins of his own violence, by attributing it to the gods." 2

It is necessary for Hippolytus to die outside the city and at the hands of the gods in order to purify the city. By being destroyed outside the city Hippolytus both literally and figuratively removes its violence. Literally, the supernatural events of the seashore would destroy Troezen, and thus by leaving the city Hippolytus diverts them. Figuratively, by suffering the absolute peak of the violence from the gods outside he protects the community from its own violence, siphoning off onto himself the tensions and disturbances of Troezen.

The attribution of violence to the gods, not man, shelters the community from the knowledge of its own violence. Poseidon and the bull do all the dirty work for Theseus and Phaedra by physically causing Hippolytus's death. While Theseus eventually worries about his responsibility, Hippolytus easily exonerates him (1448-49). The vivid, fantastic account of his destruction, though, remains in the audience's minds, and so the gods become "responsible" for man's violence. The play's last two hundred lines progressively remove blame from the human characters and shift it onto the gods. Artemis carefully explains to Theseus that his wife was noble (1301), that she suffered because of Aphrodite (1303), that she tried to overcome the goddess (1304), and that "she was destroyed unwillingly by the schemes of the Nurse" (1305), who, of course, is not divine, but an agent of divine will. ${ }^{73}$ After berating Theseus for his rashness, Artemis even mitigates his responsibility by stressing Aphrodite's

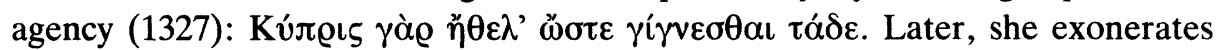
him (1433-34): "You destroyed him unwillingly [ö $\omega \omega v]$, but human beings are permitted to err with the gods allowing." She explains similarly to Hippolytus, who then laments how the goddess, not Phaedra or Theseus, destroyed him (1400-1401). Hence, Hippolytus can absolve his father (1449, his first act as an "official" cult hero), because violence has run its course and no longer is seen to belong to man.

One could object, as Pucci does, ${ }^{74}$ that Hippolytus's death neither returns order nor stops the chain of violence, since Artemis swears revenge on Aphro-

71. See Devereux (supra, n. 5: 12-13, 141-150), who argues also that Theseus might already be a projection of Hippolytus in the first place.

72. Girard (supra, n. 2 [1977]) 161. I do not want to appear to lean too heavily on Girard's thought, but here in particular he is extremely useful. His observations based on his reading of the Bacchae ring very true for the Hipp. (165): "The subject watches the monstrosity that takes shape within him and outside him simultaneously. In his efforts to explain what is happening to him, he attributes the origins of the apparition to some exterior cause. . . The whole interpretation of the experience is dominated by the sense that the monster is alien to himself."

73. The scapegoating of the Nurse here seems part of the general evasion of responsibility undertaken by all, paralleling the displacement onto the gods since she is as outside the community at the play's end as the gods.

74. Pietro Pucci, "Euripides: The Monument and the Sacrifice," Arethusa 10 (1977) 185-86. 
dite (1417-22), but I believe this objection ultimately supports my argument. Artemis stresses that she personally ( $\dot{\varepsilon} \xi \xi \dot{\varepsilon} \mu \bar{\eta} \varsigma \chi \varepsilon \varrho o ́ \varsigma, 1420)$ will avenge Hippoly-

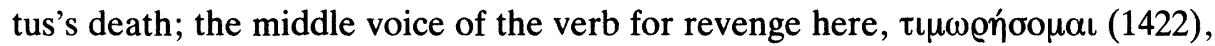
might indicate that she acts for her own benefit. Hence, action and responsibility belong to Artemis, not Hippolytus or any other human. Artemis's promise also has little to do with this play's specific action. This community's violence has spent itself by scapegoating Hippolytus; there is no reason for any more within this community now, and hence any further actions will be between the goddesses, outside this community and this play's action.

Artemis's threats, then, emphasize the transference of violence from within man to the gods. The play stresses that the sacred is violence that must be kept out of the human realm, but that Hippolytus's impious behavior incurs. The disruption of sacrifice involves gods who only bring destruction. Euripides seems to understand the necessity of scapegoating for restoring order, but he also seems to show (like Faulkner in Light in August) that scapegoating is a temporary solution - an event that must recur and a drama that must be enacted with regularity if culture is to function. And this is what Artemis promises in part: that this sequence will happen at another time in another place. ${ }^{75}$

Artemis's second promise, to establish a maiden cult to Hippolytus, whose members will sacrifice their hair to him and will always remember him in song, serves to reestablish difference through the stabilizing control of ritual and myth. ${ }^{76}$ Hippolytus's spirit will preside over the transition from virginity to the sexuality of marriage, a transition he himself failed to make, which caused the play's crisis. His avowal of virginity was thus a sacrificial crime. This ritual, then, will be a violence-preventing mediation between two poles of human existence. Walter Burkert argues that the virgin's first sexual experience resembles sacrifice "mainly because of the exclusively human phenomenon of shedding blood in first intercourse." 77 The bride, Burkert observes, needs a ritual substitute to mitigate her alienation and anxiety, one form of this being the hair sacrifice, and hence all Greek brides were required to sacrifice to appease the angry virgin goddess. Hence, the hair sacrifice averts the dangers associated with bloodshed and with incurring Artemis's wrath, mediating between virginity and sexuality by placing the maidens first symbolically in the realm of the sexual. Hippolytus can be an ideal idol for this since, unlike Artemis, he has experienced in his death the ordeals of female sexuality and the pains of giving birth. ${ }^{78}$ His ability to be a cult

75. Barrett (supra, n. 5: ad loc.) is surprisingly close to my point here: "The human conflict is resolved by death; the Olympian conflict continues, irresoluble."

76. On the function of the hair sacrifice and the Hippolytus myth for maidens, see Kenneth Reckford, "Phaethon, Hippolytus and Aphrodite," TAPA 103 (1972) 414-16; and George E. Dimock, Jr., "Euripides' Hippolytus; or, Virtue Rewarded," YClS 25 (1977) 241-42.

77. Walter Burkert, Homo Necans: The Anthropology of Ancient Greek Sacrificial Ritual and Myth (Berkeley and Los Angeles, 1983) 62.

78. See Zeitlin (supra, n. 17: 78) on the resemblance of Hippolytus's pain to childbirth and Phaedra's earlier illness. 
figure grows out of the surrogate victim's nature by being both like and unlike the groups he represents.

Hippolytus's new status fulfills the scapegoat structure's final part through his transformation from a figure of dangerous impiety, sexual anomaly, and incest into a positive mediating figure for maidens, thus endowing him with a productive role in death that he lacked in life. As with Oedipus, his death has given him power (albeit a lesser power than Oedipus's) over the living, but only because he has died the death of the scapegoat. ${ }^{79}$ The play has presented a character who, because of his excessive behavior and violent mimetic rivalries, has become less sympathetic as a character, but more acceptable as a victim. But as Hippolytus has become a victim, he has reacquired his identity and our sympathy. He can now serve a positive purpose in cult, because his victimage has displaced the conflicts he created by removing them from human responsibility.

Temple University

79. Cf. Girard (supra, n. 2 [1987]) 90. 